Журнал«Герспективитаінноваціїнауки»

(Серія«Гедагогіка», Серія«Гцихологія», Серія«Медицинв»

№2(7) 2022

УДК 159.923 .2

https://doi.org/10.52058/2786-4952-2022-2(7)-924-933

Палько Тетяна Василівна кандидат психологічних наук, доцент кафедри педагогіки та психології, Закарпатський інститут післядипломної педагогічної освіти, вул. А. Волошина, 35, м. Ужгород, тел.: (050) 536-99-05, https://orcid.org/0000-0003-2273-1472

\title{
САМЕРЕФЕРЕНЦІЯ ПРОФЕСІЙНОЇ ІДЕНТИЧНОСТІ ПЕДАГОГА В УМОВАХ «ГЛОБАЛЬНОГО СЕЛА»
}

Анотація. У статті порушуються питання, пов'язані з самореференцією ідентичності педагога в умовах «глобального села», проходження ним певних статусів ідентичності, виконання ролей та набуття певних рис, притаманних сучасному педагогу. Цифрове середовище розширює горизонт можливостей для самореференції професійної ідентичності педагога, надаючи доступ до цифрових продуктів, націлених на актуалізацію знань i навичок, оцінку конкурентоспроможності, наявного потенціалу, створення умов для отримання i самостійного освоєння нових знань, навичок і умінь віддалено, через мережу Інтернет, не обумовлених кордонами. Спілкування через педагогічні та батьківські спільноти, обмін досвідом і думками, власні самозміни через нові форми і види професійного вдосконалення під час багатьох різноманітних івентів - це той шлях самореференції, який відкрився педагогу в умовах «глобального села». Метою статті $\epsilon$ розкриття шляхів самореференції ідентичності педагога в умовах «глобального села». 3 метою їх визначення застосовано аналіз наукових розробок, психолого-педагогічної, навчальнометодичної літератури, інформаційних джерел із зазначеної вище проблематики, а також практичної діяльності у процесі підвищення кваліфікації педагогічних працівників на базі Закарпатського інституту післядипломної педагогічної освіти.

У статті висувається припущення, що саморефернцію професійної ідентичності педагога в умовах «глобального села» можна розглядати двояко. 3 одного боку, для емоційно вразливих педагогів, які ще не мають особистісного стійкого стержня у житті самореференція професійної ідентичності у таких нестабільних умовах може виявитися доволі складним процесом. 3 іншого - для педагога-професіонала особистісна ідентифікація - це сходинка до професійної ідентифікації, оскільки він має особисту стабільність і самореференція розглядається ним як шлях до самозмін.

Ключові слова: самореференція, ідентичність, «глобальне село», цифровізація.

Palko Tetiana Vasylivna Candidate of Psychological Sciences, Associate Professorat the Department of Pedagogy and Psychology, Zakarpattia Institute of Postgraduate Pedagogical Education, A.Voloshina St., 35, Uzhhorod, tel.: (050) 536-99-05, https://orcid.org/0000-0003-2273-1472 


\title{
SELF-REFERENCE OF THE PROFESSIONAL IDENTITY OF THE TEACHER IN THE CONDITIONS OF THE «GLOBAL VILLAGE»
}

\begin{abstract}
The article presents questions concerning the self-referentiality of teachers' identity in the conditions of the «global village», promotion of certain identity statuses, fulfillment of roles and loading of certain features inherent in a modern teacher. The digital environment expands the horizon of opportunities for self-references of the teacher's professional identity, providing access to digital products, influencing the activation of knowledge and navigation, assessment of competitiveness, existing capacity, creating opportunities for achieving and mastering new knowledge, navigation and incoming skills not due to borders. Communication through pedagogical and parental communities, exchange of experiences and opinions, self-change through new forms and types of professional development during many different events - this is the path of self-reference that opened to the teacher in the «global village». The aim of the article is to reveal the ways of selfreference of the teacher's identity in the conditions of the «global village». In order to determine them, the analysis of scientific developments, psychological and pedagogical, educational and methodical literature, information sources on the above issues, as well as practical activities in the process of professional development of teachers on the basis of the Zakarpattia Institute of Postgraduate Pedagogical Education. The article suggests that the self-reference of the professional identity of a teacher in a «global village» can be considered in two ways. On the one hand, for emotionally vulnerable teachers who do not yet have a stable personality in life, selfreference of professional identity in such unstable conditions can be quite a difficult process. For a professional teacher, personal identification is a step towards professional identification, because he has personal stability and self-reference is seen by him as a way to self-change.
\end{abstract}

Keywords: self-reference, identity, «global village», digitalization.

Постановка проблеми. В епоху цифровізації та діджиталізації за умов розвинених інформаційних технологій сучасне людство живе на планеті, не відчуваючи кордонів. Завдяки розгалуженій сітці соціальних мереж Facebook, Instagram, Linkedln, Profeo та іншим світ для нас стає набагато ближчим i доступнішим, наче батьківщина, де ми народилися і зростали. Ми навіть не усвідомлюємо, як швидко будь-яка подія в одній точці планети здійснює вплив на добробут і поведінку людей в усіх куточках світу. Це свідчить про тісну мережу взаємозв'язків між людьми. Вони опиняються в долі секунди в «єдиному селі», ніби мешкаючи у ньому, взаємодіючи одне з одним. Такі процеси звужують межі світу, перетворюючи його на «глобальне село». Термін «глобальне село» вперше вжито М. Мак-Люеном у творі «Галактика Гутенберга», в якому він описує, як мас-медіа долають просторові та часові бар'єри, уможливлюючи людське спілкування у небачених масштабах - i в цьому сенсі земна куля завдяки ЗМІ перетворюється на віртуальне «глобальне село» [1]. Сьогодні Інтернет належить кожному - отже, він не належить нікому та не має меж. Інтернет безпосередньо впливає на громадську думку, де б люди не перебували, та вже змінив спосіб мислення і поведінки людей у світі, який їх 
оточує. Якщо раніше ми не відчували такого глибокого занурення в умови «глобального села» завдяки тенетам Інтернету, то виклики, спричинені пандемією COVID-19 пришвидшили всі ці процеси. Спілкування через педагогічні та батьківські спільноти, обмін досвідом і думками, власні самозміни через нові форми i види професійного вдосконалення під час багатьох різноманітних івентів - це той шлях самореференції професійної ідентичності, який відкрився педагогу в умовах «глобального села».

Аналіз останніх досліджень і публікацій. Зазначені вище зміни недвозначно свідчать про завершення ери Професора: він уже «не компетентніший за мережу запам'ятовуючих пристроїв у справі передачі встановленого знання або за міждисциплінарну групу у справі розробки нових технічних прийомів чи нових ігор» [2, 130]. Ж.-Ф. Ліотар виводить важливі висновки: в залежності від того, з яким уявленням про тип суспільства ми маємо справу, такий і статус знання ми матимемо в цьому суспільстві[3]. Розмірковуючи про статус знання розуміємо, що в таких стрімких умовах розвитку цифровізації необхідно більше уваги приділяти індивідуалізації навчання, щоб допомогти здобувачу знань проявити себе в новій для нього освітній ситуації. Сьогодні, щоб стати хорошим фахівцем, потрібно напрацьовувати базу знань і набувати досвід. Щоб стати успішною людиною в майбутньому на думку Мітіо Каку: «...потрібно розвивати ті здібності, які недоступні роботам: креативність, уяву, ініціативу, лідерські якості. Суспільство поступово переходить від товарної економіки до інтелектуальнотворчої» [4]. Чим би не займалася людина, у неї повинен бути творчий підхід до виконання будь-якої справи, здатність швидко орієнтуватися в умовах «глобального села» і добре розвинена інтуїція. За такого переходу основний акцент переноситься на розвиток творчого потенціалу здобувачів освіти; розкриття їх особистісних якостей; формування здатності до пошуку нестандартних рішень під час професійних завдань і життєвих ситуацій; прагнення до самоосвіти, пошуку інформації 3 використанням новітніх цифрових засобів навчання. Функція викладача змінюється від передачі знань здобувачу освіти до організації процесу самостійного отримання ним знань за допомогою інформаційних джерел, оскільки у найближчому майбутньому освітяни 3 лекторів стануть менторами: вони будуть давати кар'єрні чи персональні поради, оцінювати роботу. Здобувачі освіти на іспитах зможуть легко відшукати відповіді на питання в Інтернеті. 3 одного боку, не потрібно буде перевантажувати мозок знаннями, основний відсоток яких, як показує практика, згодом не використовується. 3 іншого - той резерв, який звільниться в нашому мозку переорієнтується на розвиток здатності думати, аналізувати, критично мислити, аргументувати і приймати виважені рішення. «Дуже скоро такі пристрої, засновані на технологіях штучного інтелекту, будуть розташовуватися повсюдно: в квартирах, офісах, на вулицях. Досить буде наблизитися до стіни і сказати: «Я хочу поговорити з професором біології». I тут же на стіні з'явиться вчений, який може дати вам всю потрібну інформацію» [4]. Тому особлива роль в інформаційному оновленні сучасних закладів освіти залежатиме від цифрових трансформацій, архіву, реалізації таких дидактичних принципів, як: швидкість, своєчасність та ефективність у прийнятті рішень. 
Що стосується закладів вищої та післядипломної освіти, то вони повинні стати в авангарді створення власного цифрового середовища, оскільки питання організації єдиного цифрового середовища наразі активно обговорюється на вищих рівнях. Єдине цифрове середовище - це сукупність програмно-технічних засобів, призначених для накопичення, обробки, аналізу і передачі закодованих даних, а також, управління процесами, які вписані в соціальну матрицю організаційно-управлінського контуру. Різні цифрові середовища інтегруються в єдине цифрове середовище, яке характеризується великою кількістю взаємодій i, як наслідок, ставить питання до агрегації даних в єдиний механізм управління.

Цифрове середовище розширює горизонт можливостей для самореференції професійної ідентичності педагога, надаючи доступ до цифрових продуктів, націлених на актуалізацію знань і навичок, оцінку конкурентоспроможності, наявного потенціалу, створення умов для отримання і самостійного освоєння нових знань, навичок і умінь віддалено, через мережу Інтернет, не обумовлених кордонами. Яцина О.Ф. тлумачить самореференцію як самопредставлення ідентичності, сконструйоване за допомогою операцій самовизначення, самопізнання, самотворення, самовідтворення і самоздійснення у значущих комунікативних ситуаціях та як спосіб самовираження своєї індивідуальності, підгрунтям якого є інтерес суб'єкта до діяльності [5, с.770]. Такий шлях самореференції стає більш осяжним завдяки можливостям, які останнім часом відкриваються для педагогів у всіх куточках світу за допомогою мережі Інтернет. У дослідженнях Е.Еріксона формування ідентичності постає як «процес одночасного відображення і спостереження, що протікає на всіх рівнях психічної діяльності, за допомогою якого індивід оцінює себе з погляду того, як інші, на його думку, оцінюють його у порівнянні із собою...У той же час він оцінює судження про нього з погляду того, як він сприймає себе у порівнянні 3 ними й 3 типами, важливими для нього» [6, с. 32]. I дійсно, становлення професіоналізму педагога повинно грунтуватися на закономірностях самореалізації потенціалу в процесі творчої діяльності на шляху до вищих досягнень, з урахуванням об'єктивних і суб'єктивних факторів, що сприяють i перешкоджають саморозвитку.

Метою статті $\epsilon$ розкриття шляхів самореференції ідентичності педагога в умовах «глобального села». 3 метою визначення таких шляхів застосовано аналіз наукових розробок, психолого-педагогічної, навчально-методичної літератури, інформаційних джерел із зазначеної вище проблематики, а також практичної діяльності у процесі підвищення кваліфікації педагогічних працівників на базі Закарпатського інституту післядипломної педагогічної освіти.

Виклад основного матеріалу. Педагогічна діяльність і професіоналізм вчителя можуть бути оцінені 3 об'єктивних i суб'єктивних позицій. 3 об'єктивних позицій оцінюється мотивація педагога на досягнення і уникнення невдач, рівень професійних знань, творчий підхід до педагогічної діяльності, креативність вчителя, продуктивність педагогічної діяльності і, як наслідок, ступінь міцності і глибини знань здобувачів освіти, з якими працює педагог. При цьому виявляється наявність у педагога емоційної стабільності і 
професійних деформацій, можливостей саморегуляції своєї професійної діяльності і відносин з усіма учасниками освітнього процесу. 3 суб'єктивних позицій рівень професіоналізму педагога оцінюється через рівень його самореференції, яку у повсякденній рутині поточних справ не завжди педагогу вдається здійснювати.

Під час реалізації модуля «Основи андрагогіки. Психолого-фізіологічні особливості здобувачів освіти» курсів підвищення кваліфікації в Закарпатському інституті післядипломної педагогічної освіти на заняттях 3 педагогами видається можливим розгляд питання самореференції професійної ідентичності, а також підвищення мотивації педагога до ії здійснення. Так, під час вебінара у квітні 2020 року було проведено опитування (32 бажаючих взяли участь в опитуванні) щодо ролей, які виконує педагог у своїй професійній діяльності. Результати свідчать по те, що педагог замислюється над професійною самореалізацією через виконання певних ролей, які часто виражають більше соціальний характер, ніж реалізацію педагогічної діяльності (рис. 4).

\section{Які ролі виконує педагог у своїй професійній діяльності?}

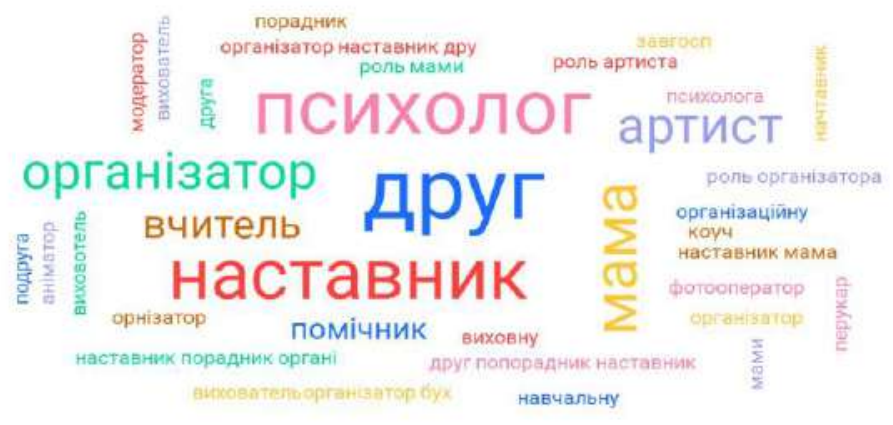

Puс.4. Скріншот стільниці під час проведення вправи «Ролі, які виконує педагог у своїй професійній діяльності» на платформі Mentimeter

Таке опитування було проведено на початку карантину і виявлено, що педагоги не ототожнювали себе 3 тою чи іншою професійною роллю, причому припускаємо, що вони не мали змоги замислитися над цим питанням через рутину повсякденних справ.

Поштовхом до самореференції професійної ідентичності, співвідносної $з$ ролями педагога стало дистанційне навчання у період пандемії, викликаної COVID-19. У цей час педагог переосмислює, беручи участь у різноманітних івентах, i врешті-решт усвідомлює значущість тих ролей, які він може виконувати i часто виконує під час своєї професійної діяльності фасилітатора, тьютора, коуча, супервізора, модератора тощо. 
Так, упродовж розкриття теми «Нові професійні ролі і завдання вчителя в контексті сучасних змін» за допомогою інструментів Google проводиться обговорення в групах (у залах ZOOM) сильних і слабких сторін різних ролей, які виконує сьогодні педагог під час освітнього процесу, що дає можливість для глибокого аналізу не тільки тих ролей, які виконують інші, але й власної самореалізації (рис.1-3).

\section{Фасилітатор}

від англ. facilitate): 1 сприяти, 2 допомагати, 3 полегшувати. Це вчитель, основне завдання якого юлягає в стимулюванні та направленні процесу самостійного пошуку інформації та спільної ціяльності учнів. Фасилітація - це організація й управління процесом обговорення певних питань тем) у групі людей.
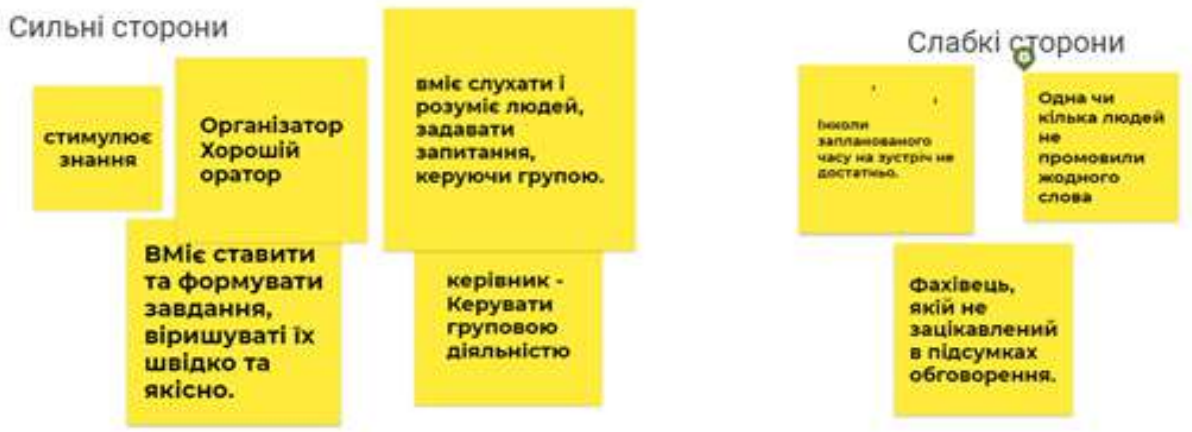

Puс.1. Скріншот стільниці під час розкриття теми «Нові професійні ролі і завдання вчителя в контексті сучасних змін» на платформі Jamboard. Розгляд ролі «педагог-фасилітатор».

\section{Педагог-супервізор}

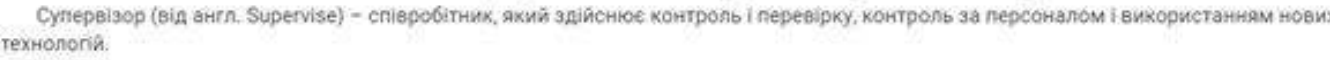

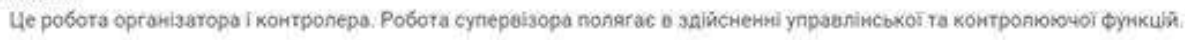

Сильні сторони

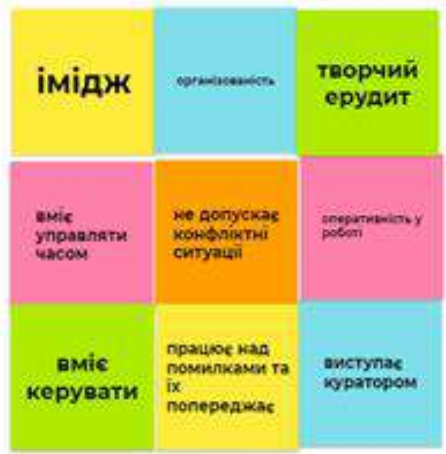

\section{Слабкі сторони}

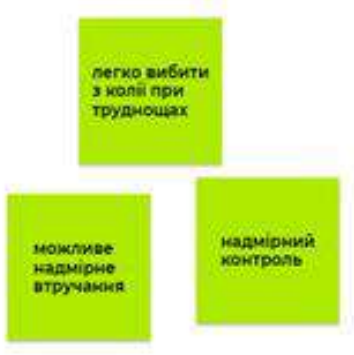

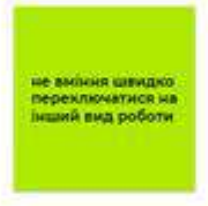

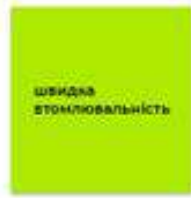

Puс.2. Скріншот стільниці під час розкриття теми «Нові професійні ролі i завдання вчителя в контексті сучасних змін» на платформі Jamboard. Розгляд ролі «педагог-супервізор». 
(від англ, tutor - учитель) - особа, що веде індивідуальні або групові заняття із учнями, студентами, репетитор, наставник, опікун.

Тьютор - ключова фігура в дистанційному навчанні, що відповідає за проведен занять з учнями, студентами.

Життева необхідність тьютора для здобувачів освіти інклюзивних груп та класі

На думку фахівців, учитель працює відповідями, а тьютор - питанням.

Сильні сторони

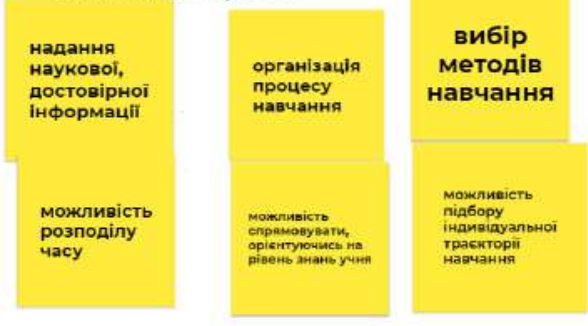

Слабкі сторони

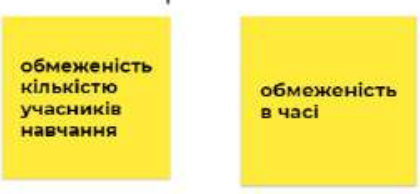

Puс.3. Скріншот стільниці під час розкриття теми «Нові професійні ролі $i$ завдання вчителя в контексті сучасних змін» на платформі Jamboard. Розгляд ролі «педагог-тьютор».

У процесі такої діяльності учителям надається можливість аналізувати сильні і слабкі сторони тієї чи іншої ролі, яку вони виконують під час освітнього процесу. Ми мотивуємо їх до власної референції професійної ідентичності. Таким чином, переосмисливши свою професійну діяльність, вже через рік після описаного вище вебінара, вчителі (в опитуванні взяли участь 42 бажаючих) виокремлюють риси сучасного педагога, які дають їм можливість творчо реалізуватися, зростати у своєму професіоналізмі, бути справедливими i відповідальними, залишаючись при цьому емпатійними, доброзичливими, щирими, добрими, люблячими особистостями.

Отже, можемо припустити, що участь у професійних спільнотах, різноманітних івентах і т.і., які стали можливими завдяки мережі Інтернет, дали змогу педагогам замислитися над своїм професійним «Я» (рис. 5).

\section{Назвіть риси, притаманні сучасному педагогу}

Puс. 5. Скріншот стільниці під час проведення вправи «Риси, притаманні сучасному педагогу» на платформі Mentimeter 
3 метою здобуття знань для виконання тісї чи іншої ролі і набуття певних рис, педагог у процесі свого розвитку може проходити 7 форм навчання, з яких три перші $\epsilon$ реактивними (пасивними), а наступні - проактивними: 1) дотримання правил наслідування чогось; 2) адаптація до існуючих умов; 3) підлаштовування під щось, пошук привабливості у зовнішньому середовищі; 4) формування власного досвіду; 5) активне експериментування; 6) самонавчання; 7) присвячення себе, місіонерство. Деякі люди так і залишаються на першій формі навчання, а деякі проходять всі сім [7]. Педагог, який володіє здатністю до самореференції долає всі сім форм навчання. Під час цього процесу він оцінює рівень задоволеності своєю педагогічною діяльністю через саморефлексію, самовизначення, самоусвідомлення, самопізнання, самоактуалізацію, самотворення, самовідтворення, самореалізацію і самоздійснення.

Таким чином, у процесі самореференції педагог проходить певні статуси ідентичності (Дж. Марсія), залежно від поєднання двох факторів: наявності або відсутності кризи у житті, наявності або відсутності особистісно значущих цілей, цінностей і переконань:

статус «досягнута ідентичність» характерний для педагога, який вже подолав період кризи та сформував певну сукупність особистісно значущих цілей, цінностей і переконань;

статус «мораторій» - перебування педагога у стані кризи ідентичності, під час якого він активно намагається розв'язати їі, шукаючи різні варіанти;

«передчасна ідентичність» притаманна педагогу, який не переживає кризи, але має певні цілі, цінності, переконання, що формуються не в результаті самостійного пошуку, а під впливом соціуму;

стан «дифузної ідентичності» властивий педагогам без стійких цілей, цінностей й переконань, які не намагаються активно їх сформувати. Такі педагоги, або ніколи не перебували у стані кризи ідентичності, або були не здатними вирішити проблеми, що з'явилися [8].

Про кризу у житті людини, яка може стати поштовхом до нових звершень, а у нашому випадку до професійного розвитку педагога, зауважує у своїх дослідженнях і Е.Еріксон: «криза означає не загрозу катастрофи, а поворотний пункт, і тим самим онтогенетичне джерело як сили, так і недостатньою адаптацією» [6, с. 125-131].

Трансформуючи погляди Е. Еріксона та Дж. Марсія у реалії сьогодення констатуємо, що сучасний педагог опинився в умовах «глобального села» та світової кризи, що опосередковано впливає на нього і мотивує його до досягнення нових цілей, які йому відкрилися через можливості мережі Інтернет. Причому, у таких умовах актуалізується і особистісна, і соціальна ідентичність педагога, оскільки часто далеке стає близьким для особистості за долі хвилини. До механізмів становлення і розвитку ідентичності Дж. Тернер зараховував: соціальну категоризацію, соціальне порівняння; соціальну ідентифікацію (персоналізацію, самовизначення, самоорганізацію), міжгрупову 
дискримінацію. Дослідник наголошує на соціальній ідентичності як структурі вищого рівня порівняно з особистісною ідентичністю [8]. У дослідженнях А. Фонарьова, «професійна ідентичність характеризується відповідністю між індивідуальними та соціальними уявленнями про професію, ії значимість для суб'єкта. Вона оцінюється на основі таких суб'єктивних показників: особистісної ідентичності (близькість уявлень про власні особистісні якості та якості, притаманні професіоналові), ціннісної ідентичності (близькість цінностей особистості й професіоналу), задоволеності працею (умовами іiі здійснення) і задоволеності професією» [9, с. 83] . Професійну ж діяльність можна розглядати як складову смислу життя людини. Ідентичними можуть вважатися педагоги-професіонали, які мають стабілізуючу базу, а також потенціал до саморефлексії, самовизначення, самоусвідомлення, самопізнання, самоактуалізації, самотворення, самовідтворення, самореалізації і самоздійснення.

Висновки. Отже, припускаємо, що саморефернцію професійної ідентичності педагога в умовах «глобального села» можна розглядати двояко. 3 одного боку, для емоційно вразливих педагогів, які ще не мають особистісного стійкого стержня у житті самореференція професійної ідентичності у таких нестабільних умовах може виявитися доволі складним процесом. 3 іншого - для педагога-професіонала особистісна ідентифікація - це сходинка до професійної ідентифікації, оскільки він має особисту стабільність і самореференція розглядається ним як шлях до самозмін.

Перспективи подальших досліджень полягають у додатковому вивченні впливу інформаційного простору на самореференцію ідентичності педагогів 3 різним ступенем досвіду, наявністю кваліфікаційної категорії, педагогічного звання тощо з метою надання методичної допомоги у проєктуванні траєкторії власного зростання.

\section{Лimepamypa:}

1. Мак-Люен Маршалл. Галактика Гутенберга: становлення людини друкованої книги / М. Мак-Люен ; пер. $з$ англ. А. А. Галушки, В. І. Постнікова. К. : Ніка-Центр. Серія «Зміна парадигми». 2015. 388 с.

2. Кун Т. Структура научных революций / Пер. с. англ. М.: Издательство АСТ, 2002. 608 с.

3. Лиотар Ж.-Ф. Состояние постмодерна / Перевод с франц. Н.А.Шматко. М.: Алетейя, 1998. 160 с.

4. Мiтiо Каку: Навчання вже не буде базуватися на запам'ятовуванні URL: https://www.dsnews.ua/society/mitio-kaku-ucheba-uzhe-ne-budet-bazirovatsya-na-zapominanii28082014231600 (дата звернення: 15.10.2021)

5. Яцина О.Ф., Самореферентність дискурсивної ідентичності // Кам'янецьПодільський. Проблеми сучасної психології. Том 30. 2015. С.764-775.

6. Эриксон Э. Идентичность: юность и кризис. Москва: Прогресс. 1996. 342 с.

7. Пан Л. В., Сисенко Н. В., Абрамович О. К. Концепція управління знаннями як новий напрям менеджменту організацій. К: Наукові записки. Том 30. Економічні науки. 2004. С. $97-102$

8. Антонова Н. Проблема личностной идентичности в интерпретации современного психоанализа, интеракционизма и когнитивной психологии // М: Вопр. психол. 1996. №1. C. 131-143. 
9. Фонарев А. Развитие личности в процессе профессионализации // Вопр. психол., 2004. № 6. C. 72-83.

\section{References:}

1. Mak-Liuen Marshall (2015). Halaktyka Gutenberga: stanovlennia liudyny drukovanoi knyhy [Gutenberg's Galaxy: the formation of the man of the printed book] (A. A. Halushky, V. I. Postnikov, Trans) Kyiv: Nika-Tsentr. Seriia «Zmina paradyhmy» [in Ukrainian]

2. Kun T. (2002). Struktura nauchnblkh revoliutsyi [The structure of scientific revolutions] (Trans). M.: Yzdatelstvo AST [in Russian].

3. Lyotar Zh.-F. (1998). Sostoianye postmoderna [Postmodern state] M.: Aleteiia [in Russian].

4. Mitio Kaku: (2014). Navchannia vzhe ne bude bazuvatysia na zapamiatovuvanni [Learning will no longer be based on memorization] URL: https://www.dsnews.ua/society/mitiokaku-ucheba-uzhe-ne-budet-bazirovatsya-na-zapominanii-28082014231600 (data zvernennia: 15.10.2021) [in Russian].

5. Yatsyna O.F. (2015). Samoreferentnist dyskursyvnoi identychnosti [Self-referentiality of discursive identity]. Kam ianets-Podilskyi: Problemy suchasnoi psykholohii. Tom 30 [in Ukrainian]

6. Эrykson Э. (1996). Ydentychnost: yunost y kryzys [Identity: youth and crisis] (N.A.Shmatko,Trans)Moskva: Prohress [in Russian].

7. Pan L. V., Sysenko N. V., \& Abramovych O. K. (2004). Kontseptsiia upravlinnia znanniamy yak novyi napriam menedzhmentu orhanizatsii. [The concept of knowledge management as a new direction of management of organizations] Kyiv: Naukovi zapysky. Tom 30. Ekonomichni nauky [in Ukrainian]

8. Antonova N. (1996). Problema lychnostnoi ydentychnosty $v$ ynterpretatsyy sovremennoho psykhoanalyza, ynteraktsyonyzma y kohnytyvnoi psykholohyy [The problem of personal identity in the interpretation of modern psychoanalysis, interactionism and cognitive psychology] // M: Vopr. psykhol. [in Russian].

9. Fonarev A. (2004). Razvytye lychnosty v protsesse professyonalyzatsyy [Personal development in the process of professionalization] M:Vopr. psykhol, № 6 [in Russian]. 